\title{
Artsopleiding en numerus fixus
}

Rond 1970 groeide de belangstelling om arts te worden sterk. De dure medische opleiding zou flink moeten worden uitgebreid om meer studenten toe te kunnen laten; meer dan waar de arbeidsmarkt eigenlijk om vroeg. Dat leek de overheid geen goed idee, en in 1972 werd een numerus fixus ingevoerd.

$\mathrm{Nu}$, bijna 30 jaar later, wordt gevraagd om het afschaffen ervan. Er is een snel groeiend tekort aan huisartsen en specialisten. Alarmerende cijfers verschijnen in de media, en de politiek - kabinet en parlement in koor - reageert direct. Het is gewoon te dol: er dreigt een artsentekort, en tegelijk zijn er scholieren die trappelen om dokter te worden, maar bij de opleiding geweerd worden. Wég met de numerus fixus dus.

Ik denk niet dat de faculteiten echt worden aangekeken op het artsentekort, maar het zou de politiek sieren als ook niet die suggestie werd gewekt. In weinig onderwerpen zijn de faculteiten zo volgzaam als in het toelatingsbeleid. De minister beslist over de arbeidsmarktfixus. De omvang van de landelijke instroom wordt door de minister bepaald. De overheid beslist dat de selectie plaatsvindt door loting. En later dat de beste vwo-ers daar niet meer aan mee hoeven te doen. Vervolgens dat er onder de andere belangstellenden kwalitatief geselecteerd moet worden. De facultei- ten experimenteren met toelatingscriteria, omdat de politiek dat wil, niet omdat er een rationele grond voor is. Al jaren breiden de faculteiten hun capaciteit uit op verzoek van de minister. Moet nu de numerus fixus opeens geheel worden afgeschaft?

Ik bestrijd niet dat een arbeidsmarktfixus niet meer juridisch handhaafbaar is. Het heeft mij zelfs verbaasd dat er nog nooit een afgewezen kandidaat op het idee is gekomen de toepassing van dit wetsartikel aan te vechten.

Maar dat de faculteiten het probleem niet zomaar kunnen oplossen, moge ook duidelijk zijn. In de instelling waar ik werk, is net een curriculum gestart, waarin kleinschaligheid en moderne onderwijskundige inzichten worden toegepast. Met veel passen en meten, lenen van onderwijsruimten en bijeenschrapen van onderwijspersoneel. Het lukt aardig. In augustus 2000 waren er echter ruim 800 belangstellenden voor de 264 te vergeven plaatsen. Wat er van het onderwijs terecht zou komen als we iedereen zouden toelaten, laat zich raden. Wordt de arbeidsmarktfixus afgeschaft, dan zullen de faculteiten zelf dus, uit zelfbehoud, een grens aan de toelating moeten stellen. Alleen op die manier kan onderwijskwaliteit behouden blijven.

Olle ten Cate 